\title{
Pruning Acer rubrum at Planting Impacts Structure and Growth After Three Growing Seasons
}

\author{
Edward F. Gilman
}

\begin{abstract}
Branches present in the tree crown at planting can become obstructions in urban landscapes, requiring large pruning cuts later and possibly creating weak structure by growing upright to comprise a large section of the crown. Pruning at planting, currently a discouraged practice, could shorten or remove selected branches and thus improve the structure of a newly planted tree. Acer rubrum L. trees planted into soil from $170 \mathrm{~L}$ containers were pruned at planting to subordinate the largest primary branches, or not. Pruning induced a $26 \%$ reduction in total cross-sectional area in the five largest primary branches. This sizable reduction in growth on pruned branches resulted in a significant reduction in aspect ratio of the largest (11\%) and three largest (10\%) branches. The negligible pruning wound from raising the crown on pruned trees would result in little trunk dysfunction when branches are later removed for clearance, and the debris would be minimal. Tree height growth after three growing seasons was unaffected by pruning; the $8 \%$ slower trunk diameter growth might be difficult to recognize in a landscape. Bending stress required to tilt trunks three growing seasons after planting was equivalent with or without pruning.

Key Words. Acer rubrum; Aspect Ratio; Formative Pruning; Inclusions; Structural Pruning; Subordination; Union Strength.
\end{abstract}

Pruning studies on bare-root nursery stock up to about $2.5 \mathrm{~m}$ tall occurred sporadically from the 1920s through the 1980s. Many of those studies evaluated whether shoot pruning was necessary to aid the transplant process by compensating for root loss that occurs when plants were dug from a field. Most studies concluded that various measures of growth were unchanged, and survival was identical, whether pruned or not at planting (e.g., Shoup et al. 1981; Evans and Klett 1984; Hummel and Johnson 1986; Duryea and Omi 1987; Chandler 1990). Compared to not pruning, crown size was generally similar or less on pruned trees one to several years after planting. Pruning in these studies varied from crown thinning to crown reduction. In addition, tree movers and field nurseries (M. Marshall, pers. comm., Marshall Tree Farm, Moriston, Florida, U.S.) routinely transplant large trees (up to $25 \mathrm{~cm}$ trunk diameter) with a tree spade without crown pruning. Supporting this practice is one study showing that crown pruning had no impact on survival of trees moved in the dormant season (Wood et al. 1990). As a result of this experience, many horticultural enterprises throughout the past 30 years have abandoned the practice of pruning trees to compensate for root loss at planting.

Although post-pruning total biomass generated on headed branches is often reduced (Maggs 1959), length of shoots growing from the pruned section of the tree can increase compared to shoots on non-pruned branches (Elfving and Forshey 1976; Wood et al. 1990). The slowing of growth on pruned branches is more pronounced as more material is removed (Gilman and Grabosky 2009). High amounts of pruning (removing $45 \%$ to $75 \%$ of foliage and buds by cutting branches) induce sprouting on certain rosaceous species and others (Shoup et al. 1981; Evans and Klett 1984; Wood et al. 1990), which could add to maintenance costs under some circumstances on some species.

Impact on root growth from pruning of bareroot trees may be more complex. There was no reduction in root growth from removing or reducing branches at planting to create and maintain a leader (i.e., structural or formative 
pruning) on 1.2 to $1.8 \mathrm{~m}$ tall whips of Malus sargentii (Evans and Klett 1984) and Prunus cerasifera 'Newport' (Evans and Klett 1985). In contrast, several studies found root growth was reduced with pruning, especially at higher pruning amounts (Head 1967; Fordham 1972).

With no consistent advantage of pruning at planting for the purpose of compensating for root loss, focus in the last few decades has shifted toward the improvement of branch and trunk structure. Many apple and pear orchards began pruning young whips at planting to craft a structure that allowed for clearance under the tree and developed a structure that supports fruit load (Forshey et al. 1992). Today, trees with large dominant trunks and much smaller branches (i.e., those with small aspect ratios) can be seen in apple orchards across North America (pers. obs.). Millions of trees are now pruned at or soon after planting each year in shade-tree nurseries. This is to train to one central leader and for clearance of lower trunk (K. Warren, pers. comm., Schmidt's Nursery, Boring, Oregon, U.S.; M. Marshall, Marshall Tree Farm, Moriston, Florida, U.S.). Some tree nut crop managers are also beginning to experiment with central leader structure.

Pruning one stem of a codominant stem pair to encourage the other stem to grow faster has been referred to as structural or formative pruning (Gilman and Lilly 2008). There are several studies supporting this concept. One on seedlings grown in an open landscape on California coast live oak (Quercus agrifolia N'ee) and valley oak (Q. lobata N'ee) found that the headed or thinned codominant stem grew more slowly than the non-pruned stem (Downer et al. 1994). Fumey et al. (2011) also showed a shift in growth from the pruned to the non-pruned portion of one-year-old apple seedlings. Structural or formative pruning seeks to enhance growth on the non-pruned leader by reducing growth rate on the branches with the largest aspect ratios; these are usually the largest branches on the tree.

Recently, studies have begun to evaluate the impact of pruning at planting on larger trees with the intention of improving branch structure in the urban landscape. One showed no reduction in trunk diameter growth rate measured four years after planting as a result of pruning at planting to improve structure (Kristofferson et al.
2010; although unreported, communication with the author confirmed no more than about 30\% of foliage was removed from any single branch). Despite no reduction in trunk growth rate, branch aspect ratio decreased slightly, but significantly, over a four-year period as a result of pruning.

The purpose of this study was to evaluate impact on distribution of large branches, aspect ratio, growth, and anchorage from pruning to reduce length of the largest primary branches when planting into landscape soil.

\section{MATERIALS AND METHODS}

Acer rubrum L. 'Florida Flame' (propagated from cuttings) were pruned twice annually for three years by the same person to craft a single central leader during nursery production in plastic containers in Gainesville, Florida, U.S., USDA hardiness zone 8b. A single leader was produced in the nursery by reducing the length of the largest diameter branches at each pruning using reduction and heading cuts. Trees were planted into field soil in May 2011 from $170 \mathrm{~L}$ round plastic containers. Soil was Millhopper fine sand (loamy, siliceous, hyperthermic Grossarenic Paleudults) with less than $2 \%$ organic matter. All finished trees had the lower $1.2 \mathrm{~m}$ of trunk clear of branches and met Florida \#1 grade (no branches larger than two-thirds trunk diameter in the lower half of the tree) of the Florida Grades and Standards for Nursery Plants (Anonymous 1998). Mean trunk diameter $15 \mathrm{~cm}$ from ground (caliper) was $67 \mathrm{~mm}$ and tree height was $5.4 \mathrm{~m}$ at planting; this size tree is commonly planted in a number of moist-climate regions across the globe. Trees were spaced $2.4 \mathrm{~m}$ apart in four rows of 16 trees, with the eastern rows assigned to one block and the western rows to another. All 16 trees in one row of each block were structurally pruned at planting; the other row of 16 trees in each block was not pruned at planting (32 trees were pruned at planting, and 32 were not pruned). Treatments were assigned randomly to the two rows in each block.

Structural pruning consisted of reducing the length of the largest diameter primary branches [i.e., those attached to the trunk that were larger than 0.5 aspect ratio $(B \div A$, Figure 1) estimated just distal to the union] that originated in the lower $80 \%$ of the crown. Branches originating from the top $20 \%$ of the crown were not pruned at plant- 
ing. Pruning cuts (reduction cuts, Gilman and Lilly 2008) up to about $15 \mathrm{~mm}$ diameter removed about half (50\%, estimated) of the foliage on the pruned primary branches. Reduction cuts were made back to lateral branches that were about one-third of the diameter of the cut; the retained lateral branch was oriented away from the central leader, where possible. Some double reduction cuts were made on pruned primary branches (Figure 1). Heading cuts were made in those few cases where the retained lateral branch had no branch at the position needed to remove an estimated $50 \%$ of foliage from the primary (Figure 1). No branches were removed at the trunk. Two to six primary branches were pruned on each tree depending on crown structure. An estimated $15 \%$ or $20 \%$ of the foliage on the entire tree was removed with pruning. Trees were not pruned after planting except for the treatments described.

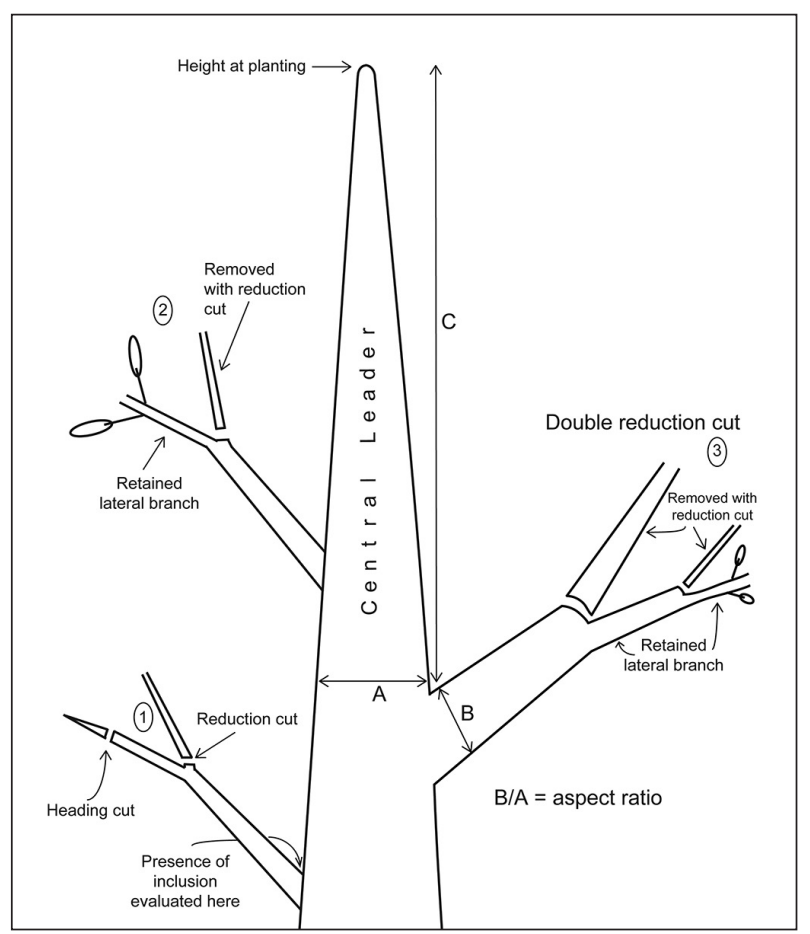

Figure 1. Pruning on primary branches $>0.5$ aspect ratio was accomplished in one of three ways: 1,2 , or 3 . Sections A, B, and $C$ were measured for each of the five primary branches with the largest diameter.

Trees were irrigated daily in the growing season for the duration of the study with three emitters directing water onto the root ball. Fertilizer (400 g; $20 \mathrm{~N}, 0$ P, $4.8 \mathrm{~K}$ ) was applied June 2011, April 2012, July 2012, and April 2013 to an area of $1.2 \mathrm{~m}^{2}$ around the trunk. Chipped, whole-tree, lineclearance pruning debris was applied as mulch 1.8 $\mathrm{m}$ wide and $8 \mathrm{~cm}$ deep down each row centered on trunks. No mulch was applied to the root ball surface and mulch was not re-applied. Periodic glyphosate applications controlled weeds. Vegetation between rows was periodically mowed.

Trunk diameter $30 \mathrm{~cm}$ above soil (calculated from circumference measured with a diameter tape) and tree height to the topmost bud were measured at planting (May 2011) and at the completion of the study (August 2013), providing data from three growing seasons. Basal diameter of the five largest primary branches at the conclusion of the study was measured just beyond the union with a diameter tape (position B, Figure 1), as was the diameter of the trunk just above the union (position A, Figure 1). Distance between tree top at planting and the union with the trunk (distance C, Figure 1) was recorded for each of these five largest primary branches. Bark inclusions in these five unions were visually evaluated as either 1) inclusion present (inclusion currently forming as indicated by a crack in the top of the union or no branch bark ridge currently forming) or 2) inclusion absent (a single branch bark ridge along $100 \%$ of the union). When in question, the union was pulled apart to confirm absence or presence of inclusions. Percentage total branch cross-sectional area (CSA) growing from unions with inclusions was calculated as: CSA of branches with inclusions $\div$ total CSA of the five largest branches (with or without inclusions) $\times 100$.

To evaluate anchorage in a strong storm, all 64 trunks were pulled during the week August 14-21, 2013 (one block each rain-free day) with an electric winch attached to a cable about $1.2 \mathrm{~m}$ from the ground. Trees were pulled in the 10 degree north azimuth direction and the cable remained parallel to ground. A $3,629 \mathrm{~kg}$ capacity load cell (SSM-AF-8000; Interface Inc., Scottsdale, Arizona, U.S.) was placed in-line with the pulling cable. An inclinometer (model N4; Rieker Inc., Aston, Pennsylvania, U.S.) was mounted to a fabricated steel plate $(5.1 \mathrm{~cm} \times 7.6 \mathrm{~cm})$. The plate was secured to trunk base $15 \mathrm{~cm}$ from soil surface, which was just above the swollen flare at the base of the tree. Ten days prior to pulling $42 \mathrm{~mm}$ rainfall occurred; 71 $\mathrm{mm}$ fell the day after the first block was pulled and $14 \mathrm{~mm}$ fell the day after the third block was pulled. 
The cable was pulled at $2 \mathrm{~cm} \cdot \mathrm{s}^{-1}$ until the inclinometer tilted five degrees from vertical start position and then the cable was let slack. Data from load cell and inclinometer were collected at $2 \mathrm{~Hz}$ by Data Acquisition System (National Instruments Corporation, Austin, Texas, U.S.) and recorded on a laptop. Data was displayed in real-time during pulling tests on a laptop running LabView software (v: 7.0; National Instruments, Austin, Texas, U.S.). Trunk bending stress (Kane et al. 2008) at position of inclinometer was calculated as: (pulling force $\times$ distance from pulling point to inclinometer $\times$ trunk radius at inclinometer $) \div(0.25 \pi \times$ trunk radius ${ }^{4}$ ). Trunk radius was calculated by halving the diameter measured with a diameter tape.

The t-test in SAS (v: 9.2; Cary, North Carolina, U.S.) was used to compare means between treatments. Significance was established at $P<0.05$.

\section{RESULTS AND DISCUSSION}

Tree height increase during the three growing seasons following planting was not affected by structural pruning at planting. Although trunk diameter increase was statistically smaller on pruned trees, the $5 \mathrm{~mm}(8 \%)$ smaller trunk might be difficult to recognize in a landscape (Table 1). Others also found little impact of pruning on crown growth and trunk diameter. For example, pruning did not alter tree height or trunk diameter of rose gum (Eucalytpus grandis W. Hill ex Maiden) (Bredenkamp et al. 1980), or crown volume of black walnut (Juglans nigra L.) (Funk 1979). Neilsen and Pinkard (2003) showed that light crown-raising (removing all branches in the lower $45 \%$ of tree height) had no effect on growth of Monterey pine (Pinus radiata D. Don), but heavier pruning (60\% or $75 \%$ removal of foliage and associated branches) decreased trunk diameter growth, stem volume, and tree height in forest plots.

The CSA of the largest-diameter branch and the largest-diameter branch with a bark inclusion in the union was reduced ( $31 \%$ and $32 \%$, respectively) as a result of pruning at planting compared to the largest branch on non-pruned trees (Table 1). In addition, percent of the total branch CSA (five largest branches) that had inclusions in the union was reduced $23 \%$ with pruning. Branches with inclusions are considered weakly attached to the trunk (Smiley 2003), so reducing their size should help reduce the likelihood of union breakage, although this remains unreported. Total CSA in the five largest branches was also reduced $26 \%$ with pruning. The slower growth on the largest branches of pruned trees resulted in a significant reduction in aspect ratio of the largest (11\%) and three largest $(10 \%)$ diameter branches. When branch CSA and aspect ratio were multiplied one by the other for each branch and summed across branches (size-ratio) as a means of evaluating both factors together, there was a $31 \%$ (mean among all five branches) and 37\% (the largest branch) reduction on pruned trees (Table 1). Other trees also showed a reduction in growth rate (Downer et al. 1984; Fumey et al. 2010) and aspect ratio on the pruned branch over a three- (Gilman and Grabosky 2009) or four-year (Kristoffersen et al. 2010) period. Slower accumulation of branch mass from reduced branch growth rate-combined with a reduction in aspect ratio-should reduce risk of union failure.

Similar to the current study, Kristoffersen et al. (2010) used one or more reduction cuts on the largest aspect ratio branches (up to an estimated 25\%$30 \%$ foliage/buds) removed either at planting, two years later, or both to subordinate branches to the leader. The small but significant change in aspect ratio over four years (for the at-planting pruning treatment) that occurred may be related to the small amount ( $<30 \%$ material removed) of pruning. Gilman and Grabosky (2009) also showed a small reduction in aspect ratio when $25 \%$ was removed, but a more pronounced reduction as pruning amount increased to $50 \%$ and $75 \%$. This lends support to the notion that a pruning amount $>25 \%$ or $30 \%$ applied to an individual branch or stem is needed to significantly reduce the growth rate, and therefore the aspect ratio, on a pruned branch.

The pruning conducted at planting in the current study impacted the distribution of subsequent growth with more growth occurring in the leader than in pruned branches. For example, the distance from the tree top at planting downward to the highest branch that was among the five largest (C, Figure 1) was reduced with pruning by $22 \%$ (Table 1 ). This provided evidence that pruning shifted growth from the lower crown into the leader and existing non-pruned branches in the upper crown. In contrast, non-pruned trees developed more growth in the lower portion of the crown as indicated 
Table 1. Response of Acer rubrum L. 'Florida Flame' three growing seasons after structural pruning at planting.

\begin{tabular}{|c|c|c|c|}
\hline Measured tree attribute & Pruned at planting & Not pruned at planting & $\%$ reduction from pruning ${ }^{z}$ \\
\hline Trunk diameter increase $(\mathrm{cm})$ & $5.6 \mathrm{~b}^{\mathrm{y}}$ & $6.1 \mathrm{a}$ & 8 \\
\hline Tree height increase $(\mathrm{m})$ & 2.5 & 2.7 & $\mathrm{~ns}^{\mathrm{x}}$ \\
\hline $\mathrm{CSA}^{\mathrm{w}}$ of five largest-diameter branches $\left(\mathrm{cm}^{2}\right)$ & $41.3 \mathrm{~b}$ & $55.5 \mathrm{a}$ & 26 \\
\hline CSA of largest-diameter branch $\left(\mathrm{cm}^{2}\right)$ & $14.2 \mathrm{~b}$ & $20.6 \mathrm{a}$ & 31 \\
\hline $\begin{array}{l}\text { Distance from top of tree at planting to the } \\
\text { union of the highest branch that is } \\
\text { among the five largest }(\mathrm{m})\end{array}$ & $0.7 \mathrm{~b}$ & $0.9 \mathrm{a}$ & 22 \\
\hline Aspect ratiov of the five largest-diameter branches & 0.55 & 0.59 & ns \\
\hline Aspect ratio of the three largest-diameter branches & $0.60 \mathrm{~b}$ & $0.67 \mathrm{a}$ & 10 \\
\hline Aspect ratio of largest-diameter branch & $0.68 \mathrm{~b}$ & $0.76 \mathrm{a}$ & 11 \\
\hline $\begin{array}{l}\text { CSA of largest-diameter branch with bark } \\
\text { inclusion }\left(\mathrm{cm}^{2}\right)\end{array}$ & $11.0 \mathrm{~b}$ & $16.1 \mathrm{a}$ & 32 \\
\hline Size-ratio ${ }^{\mathrm{u}}\left(\mathrm{cm}^{2}\right)$ & $4.5 \mathrm{~b}$ & $6.5 \mathrm{a}$ & 31 \\
\hline Size-ratio on branch with largest CSA $\left(\mathrm{cm}^{2}\right)$ & $9.7 \mathrm{~b}$ & $15.5 \mathrm{a}$ & 37 \\
\hline $\begin{array}{l}\text { Number of five largest-diameter branches with } \\
\text { an inclusion in the union }\end{array}$ & 3.1 & 3.3 & ns \\
\hline Percent total CSA with inclusions in union & $40.7 \mathrm{a}$ & $52.6 \mathrm{~b}$ & 23 \\
\hline Bending stress to pull trunks to five degrees $\left(\mathrm{MN} / \mathrm{m}^{2}\right)$ & 22.2 & 21.7 & ns \\
\hline \multicolumn{4}{|c|}{$\begin{array}{l}{ }^{\mathrm{z}} \text { Percent reduction }=(\text { not-pruned }- \text { pruned }) / \text { not-pruned } \times 100 . \\
\text { y } \text { Means within rows followed by the same letter are not statistically different }(\mathrm{t}-\text { test }) \text { at } P<0.05 \text {. } \\
{ }^{\mathrm{x}} \mathrm{ns}=P>0.05 \text {. } \\
\text { w } \mathrm{CSA}=\text { cross-sectional area. } \\
{ }^{\mathrm{v}} \text { Aspect ratio }=\text { branch diameter } \div \text { trunk diameter just beyond union. } \\
\text { u Size-ratio = branch CSA } \times \text { aspect ratio. }\end{array}$} \\
\hline
\end{tabular}

by a greater distance from the tree top at planting to the topmost, largest branch. The balance between 1) retaining non-pruned branches in the upper crown to induce more growth on the leader, and 2) pruning low large branches to slow their growth in the lower crown, has not been studied. Finding this balance for a variety of species, tree ages, and cultural conditions will help professionals write meaningful pruning specifications.

Although foresters do not agree on the merits of pruning seedlings at planting, the improved structure appears clear in the scientific literature, and on balance, South (1998) states it is likely beneficial. Survival appears to increase slightly (although it can be close to $100 \%$ even without pruning, South 1998) and wood quality can be enhanced because trunks are straighter when seedlings are pruned to one leader at planting. Early experiments with larger bare-root whips used in landscape plantings found no influence of pruning at planting on tree survival and regrowth (Shoup et al.1981; Evans and Klett 1984; Evans and Klett 1985). Data from the current study on larger well-irrigated trees with good vitality ( $67 \mathrm{~mm}$ trunk diameter) planted from containers appears to show the same results as that of Kristoffersen et al. (2010) on $42 \mathrm{~mm}$ trunk diameter non-irrigated field grown nursery trees. Structural pruning re-distributes future growth from existing large branches to the leader higher in the crown with a significant $(P<0.05)$ but small $(8 \%)$ reduction in trunk diameter growth and no impact on height. Irrigated or not, the response appears to be universal across tree size and nursery production method.

Bending stress $\left(22 \mathrm{MN} / \mathrm{m}^{2} ; \mathrm{SD}=2.5\right)$ to pull trees up to five degrees was not impacted by pruning at planting (Table 1). No popping sounds indicative of root breakage were detected while sitting next to the trees during pulling. The lack of impact on bending stress to tilt trunks in the current study appears to support the findings of Evans and Klett (1984; 1985) who showed no effect on root growth following pruning that removed up to $75 \%$ of buds using crown thinning and reduction. In contrast, Gilman et al. (2006) showed reduced anchorage on Quercus virginiana Mill. when branches were removed prematurely from the lowest $1.5 \mathrm{~m}$ of the trunk in a nursery. Reduced anchorage was attributed to less trunk diameter and root growth compared to trees with low branches retained for longer; perhaps the proximity of the removed foliage to the root system was responsible for reduced growth and anchorage. Foliage and branches removed in the current study were several meters above the root system.

Many current University Extension documents recommend withholding pruning at planting until trees are well established. This may be a carryover from the earlier literature that showed no influence of pruning on post-planting growth rates or sur- 
vival, and it was therefore assumed foresters had no need to prune to compensate for root loss when trees were dug from a field nursery. As a sign of change in the profession, the International Society of Arboriculture's Best Management Practices (Watson 2014) states that trees can be pruned at planting to develop strong structure and presents a method (Figure 1) similar to that tested in the current study.

Reducing growth rate on large branches in young trees prepares branches in the lower $5 \mathrm{~m}$ of the trunk and crown for their eventual removal, which is typically necessary for clearance in urban and suburban streets and other locales (Kristoffersen et al. 2010). Pruning to reduce the aspect ratio by slowing their growth rate keeps branches small, causing only a negligible pruning wound and little trunk dysfunction when they require removal (Eisner et al. 2002). Moreover, branches with a small aspect ratio are well attached to the trunk (Gilman 2003; Kane et al. 2008). In addition, slowing growth on large, upright-oriented branches in the lower $5 \mathrm{~m}$ of the trunk is likely to reduce development of the somewhat-weaker upright tree structure (Miesbauer et al. 2014). Upright branches can also suppress the leader by shading it from one side, and both can become long with poor taper. Kristoffersen et al. (2010) also advises pruning at or soon after planting to reduce growth rate on these large low branches to improve subsequent tree structure and health following their removal for clearance.

\section{CONCLUSION}

Other than a small but significant $8 \%$ reduction ( $5 \mathrm{~mm}$ ) in trunk diameter growth (but no impact on height), there appear to be no downsides to pruning the largest branches at planting by reducing their length with reduction or heading cuts, thus suppressing their growth. The reduction in aspect ratio on pruned branches shifted the largest branches to higher in the crown. This will provide for better clearance and will result in small pruning wounds due to a reduction in relative branch diameter in the lower portion of the trunk. Debris requiring disposal should be reduced compared to trees not pruned at planting.
Acknowledgments. Thank you to the TREE Fund and Greatsoutherntreeconfererence.org for partial funding.

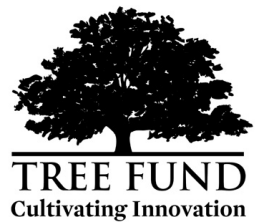

\section{LITERATURE CITED}

Anonymous. 1998. Florida Grades and Standards for Nursery Plants. Florida Department of Agriculture, Tallahassee, Florida.

Bredenkamp, B.V., F.S. Malan, and W.E. Conradie. 1980. Some effects of pruning on growth and timber quality of Eucalyptus grandis in Zululand. South African Forestry Journal 114:29-34.

Chandler, C.K. 1990. Comparison of pruned and unpruned pear seedlings for survival and growth. HortScience 25:123.

Downer, A.J., M. Shaw, and D. Pittenger. 1994. The effect of pruning on branch growth in two oak species. HortScience 29:550, Abstract \#815.

Duryea, M.L., and S.K. Omi. 1987. Top pruning Douglas-fir seedlings: Morphology, physiology, and field performance. Canadian Journal of Forest Research 17:1371-1378.

Eisner, N., E.F. Gilman, and J. Grabosky. 2002. Branch morphology impacts compartmentalization of pruning wounds. Journal of Arboriculture 28:99-105.

Elfving, D.C., and C.G. Forshey. 1976. Growth and fruiting responses of vigorous apple branches to pruning and branch orientation treatments. Journal of American Society for Horticulture Science 101:290-293.

Evans, P.S., and J.E. Klett. 1984. The effects of dormant pruning treatments on leaf, shoot, and root production from bare-root Malus sargentii. Journal of Arboriculture 10:298-302.

Evans, P.S., and J.E. Klett. 1985. The effects of dormant branch thinning on total leaf, shoot, and root production from bare-root Prunus cerasifera 'Newport'. Journal of Arboriculture 11:149-151.

Fordham, R. 1972. Observations on the growth of roots and shoots of tea (Camellia sinensis L.) in southern Malawi. Journal of Horticultural Science 47:221-229.

Forshey, C.G., D.C. Elfving, and R.L. Stebbins. 1992. Training and pruning apple and pear trees. American Society for Horticulture Science. Alexandria, Virginia.

Fumey, D., P. Lauri, Y. Guedon, C. Godin, and E. Costes. 2011. How young trees cope with removal of whole or parts of shoots: An analysis of local and distant responses to pruning in 1-year-old apple (Malus $\times$ domestica; Rosaceae) trees. American Journal of Botany 98:1737-1751.

Funk, D.T. 1979. Stem form response to repeated pruning of young black walnut trees. Canadian Journal of Forest Research 9:114-116.

Gilman, E.F. 2003. Branch to stem ratio affects strength of attachment. Journal of Arboriculture 29:291-294.

Gilman, E.F., and J. Grabosky. 2009. Growth partitioning three years following structural pruning of Quercus virginiana. Arboriculture \& Urban Forestry 35:281-286.

Gilman, E.F., and S. Lilly. 2008. Best Management Practices: Pruning, second edition. International Society of Arboriculture, Champaign, Illinois, U.S.

Gilman, E.F., P. Anderson, and C. Harchick. 2006. Pruning low branches of live oak (Quercus virginiana Mill.) cultivars and seedlings during nursery production: Balancing growth and efficiency. Journal of Environmental Horticulture 24:201-206. 
Head, G.C. 1967. Effects of seasonal changes in shoot growth on the amount of unsuberized root on apple and plum trees. Journal of Horticultural Science 42:169-180.

Hummel, R.L., and C.R. Johnson. 1986. Influence of pruning at transplanting time on growth and establishment of Liquidambar styraciflua L., sweetgum. Journal of Environmental Horticulture 4:83-86.

Kane, B., R. Farrell, S.M. Zedaker, J.R. Loferski, and D.W. Smith. 2008. Failure mode and prediction of the strength of branch attachments. Arboriculture \& Urban Forestry 34:308-316.

Kristoffersen, P., O. Bühler, S. Ugilt Larsen, and T.B. Randrup. 2010. Growth of newly established roadside trees in response to weed control and pruning. Arboriculture \& Urban Forestry 36:35-40.

Maggs, D.H. 1959. The pruning response of one-year apple trees. Annals of Botany 23:319-330.

Miesbauer, J., E.F. Gilman, F. Masters, and R. Nitesh. 2014. Impact of branch orientation on breaking stress in Liriodendron tulipifera L. Urban Forestry \& Urban Greening 13:526-533.

Neilsen, W.A., and E.A. Pinkard. 2003. Effects of green pruning on growth of Pinus radiata. Canadian Journal of Forest Research 33:2067-2073.

Shoup, S., R. Reavis, and C.E. Whitcomb. 1981. Effects of pruning and fertilizers on establishment of bare-root deciduous trees. Journal of Arboriculture 7:155-157.

Smiley, E.T. 2003. Does included bark reduce the strength of codominant stems? Journal of Arboriculture 29:104-106.

South, D.B. 1998. Effects of top-pruning on survival of southern pines and hardwoods. General Technical Report Southern Research Station, USDA Forest Service (SRS-20):3-8.

Watson, G.W. 2014. Best Management Practices: Tree Planting. International Society of Arboriculture. Champaign, Illinois, U.S.

Wood, B.W., J.A. Payne, and O. Jones. 1990. Transplanting bearing pecan trees. HortScience 25:216-218.

\author{
Edward F. Gilman \\ Professor \\ Environmental Horticulture Department \\ University of Florida \\ Gainesville, Florida, U.S.
}

Zusammenfassung. Bei der Pflanzung von Bäumen in der urbanen Landschaft können Äste in der Krone zu einem Hindernis werden; sie erfordern später große Schnittflächen und kreieren möglicherweise eine schwache Struktur, indem sie gerade hoch wachsen, um einen großen Bereich der Krone auszumachen. Ein Rückschnitt während der Pflanzung, gegenwärtig eine untergeordnete Praxis, könnte ausgewählte Äste einkürzen oder entfernen und so die Struktur eines neu gepflanzten Baumes verbessern. Acer rubrum L.Bäume aus 1701 Containern wurden in den Boden gepflanzt und dabei die größten primären Äste massiv eingekürzt oder nicht. Der Rückschnitt führte zu einer 26\% Reduktion der gesamten Durchschnittsfläche bei den fünf größten primären Ästen. Diese beträchtliche Reduktion des Wachstums bei geschnittenen Ästen führte zu einer signifikanten Reduktion des Längenverhältnisses des größten (11\%) und der drei größten (10\%) Äste. Die vernachlässigbaren Schnittwunden vom Hochziehen der Krone für das Lichtraumprofil würden zu kleinen Stammdysfunktionen führen, wenn die Äste später entfernt würden und die Abfälle wären gering. Die Baumhöhe war nach drei Wachstumsperioden unbeeinflusst durch den Rückschnitt. Das um 8 \% geringere Stammdurchmesserwachstum kann in der Landschaft nur schwer erkannt werden. Der erforderliche Biegestress, um den Stamm drei Wachstumsperioden nach der Pflanzung abzuknicken war mit und ohne Rückschnitt gleich.

Resumen. Las ramas en árboles recién plantados pueden convertirse en obstáculos en paisajes urbanos, requiriendo grandes cortes de poda más tarde y creando posiblemente una estructura débil por el crecimiento vertical al suprimir una gran parte de la copa. La poda al momento de la plantación (en la actualidad una práctica no recomendada), podría acortar o eliminar ramas seleccionadas y así mejorar la estructura de un árbol recién plantado. En el momento de la plantación se podaron árboles de Acer rubrum L. crecidos en contenedores de $170 \mathrm{~L}$ subordinando o no las ramas primarias. La poda redujo un $26 \%$ en el área de sección transversal total en las cinco ramas primarias más grandes. Esta considerable reducción en el crecimiento en las ramas podadas resultó en una disminución significativa en la relación de aspecto de la rama más grande (11\%) y las tres más grandes (10\%). La insignificante herida de poda por la elevación de la copa podría resultar en disfunción mínima del tronco cuando las ramas sean eliminadas más tarde para el dar espacio y los restos serían mínimos. El crecimiento en altura del árbol después de tres temporadas de crecimiento no se vio afectado por la poda; el crecimiento del diámetro del tronco $8 \%$ más lento podría ser difícil de reconocer en un paisaje. El esfuerzo de flexión requerido para inclinar troncos después de tres temporadas de crecimiento fue equivalente con o sin poda. 